\title{
Comparative Study of Conventional Groundwater Quality Results with WQI Technique: A Case Study of Surjani Town, Karachi, Pakistan
}

\author{
Adnan Khan ${ }^{1}$, Aasma Khan ${ }^{2}$, Bisma Naz ${ }^{1} \&$ Rukhsar $^{1}$ \\ ${ }^{1}$ Department of Geology, University of Karachi, Pakistan \\ ${ }^{2}$ Department of Chemistry, University of Karachi, Pakistan \\ Correspondence: Adnan Khan, Department of Geology, University of Karachi, Pakistan. Tel: 923-0036-35848. E- \\ mail: adkhan@uok.edu.pk
}

Received: November 1, 2020 Accepted: November 12, 2020 Online Published: November 19, 2020

\begin{abstract}
Present study is aimed to calculate the water quality index (WQI) of Surjani Town by using weighted arithmetic index method to assess its suitability for drinking purpose. For calculating WQI, 12 parameters (pH, TDS, EC, Hardness, $\mathrm{Na}, \mathrm{Ca}, \mathrm{K}, \mathrm{Mg}, \mathrm{HCO}_{3}, \mathrm{SO}_{4}, \mathrm{NO}_{3}$ and $\mathrm{Cl}$ ) have been taken into account. Except $\mathrm{pH}$, all physicochemical parameters are exhibiting the maximum prominence in WQI quality rating scale (Qn) which suggests that groundwater is highly polluted. The computed value of water quality index (WQI= 331.62) is also found to be high which is comparable with enormously high concentrations of physicochemical parameters that are violating the WHO admissible limit for drinking purpose. Results revealed that the groundwater is under the influence of anthropogenic activity from nearby Jam Chakro solid waste dumping site. It is concluded that groundwater is highly deteriorated which is immensely inappropriate for drinking purpose according to WQI rating score.
\end{abstract}

Keywords: Groundwater Quality, Quality Rating Score (Qn), Unit weight (Wn), Weighed Arithmetic Index, WQI, Anthropogenic Activity, Surjani Town

\section{Introduction}

Water quality assessment is one of the most important aspects which determine the chemical, physical and biological characteristics of water with respect to its suitability for a particular purpose i.e. drinking, irrigation, fishing and swimming. (Diersing N. 2009; Sargaonkar, et al., 2003; Khan, et al., 2003). Generally, traditional groundwater quality assessment consists of comparing the results of individual water quality parameters with guideline or standard values based on allocated water use. This type of assessment is simple and detailed but insufficient to provide a whole and interpreted picture of water quality (Abtahi, et al., 2013). For this purpose, a number of water quality indices have been developed to summarize groundwater quality data into an integrated indicator value. Hence, WQI method has been discovered which is a useful and an efficient technique to assess the groundwater quality (Khwakaram, et al., 2012). Horton (1965) proposed the first WQI by weighting some water quality variables, and then it was further modified by Brown, et al. (1970). Besides, WQI is a dimensionless number which transforms complex water quality data into a single numerical score using mathematical tools (Srebotnjak, et al., 2012; Lumb, et al., 2011) which provides an extensive interpretation of the water quality and its suitability for various purposes (Abbasi 2002). Although, it is commonly used for detection and evaluation of water pollution (Priya and Vidya 2019). For establishment of WQI, the standard guideline values are used for each physicochemical parameter. The calculated WQI value is then classified into five categories which are ranging from 0 to 100 and classifies water bodies as excellent (0-25), good (25-50), fair (51-75), poor (76-100), very poor (101-150) and unfit for drinking (>150) (Brown, et al., 1972).

In order to testify this method and to classify the water quality, present study is aimed at assessment of groundwater data of Surjani Town which has already been declared unfit for drinking purpose due to extremely high concentration of measured parameters which is consistent with the transportation of leachate from nearby landfill site (Khan, et al., 2020). 


\section{Materials and Methods}

\subsection{Study Area}

Study area is located in the northwest of Karachi city which lies between $25.00942^{\circ} \mathrm{N}$ to $67.417^{0} \mathrm{E}$ (Fig. 1). Geologically, Surjani Town is resting on Gaj Formation of Miocene age which mainly comprises clastic sediments (sandstone and shale) with subordinate limestone. Study area sets on the common flank of Lalji syncline (western flank) and Manghopir anticline (eastern flank). It is the largest subdivision of Gadap Town which spreads over a land of $1200 \mathrm{sq} . \mathrm{km}$. A landfill site is also located in the vicinity of study area at a distance of approximately $7 \mathrm{~km}$. Surjani town is an affordable and low-income locality where lower to middle class is being accommodated. Due to shortage of municipally supplied water, residents of study area are highly depending on the groundwater for domestic purpose and extract through electrically pumped bore wells.

\subsection{Sample Collection and Analysis}

Groundwater samples were carefully analyzed in the laboratory for its physico-chemical characteristics by standard analytical techniques (Table 1). Groundwater samples $(n=28)$ were collected from wells at variable depth range (35-220 ft.) through electrically pumped wells. Well water was pumped for 2 to 10 minutes subject to the depth of well. Plastic bottles of $1000 \mathrm{ml}$ capacity were used for sample collection to determine physicochemical parameters. Bottles of $100 \mathrm{ml}$ capacity were also used for nitrate determination in which about $1 \mathrm{ml}$ of boric acid solution (1\%) was added to cease any further reaction. Sample bottles were thoroughly washed with distilled water and rinsed properly with well water. The field coordinates of sample locations were noted by using GPS (Global Positioning System) and plotted on the Google image (Fig. 1).

\subsection{Determination of Water Quality Index (WQI)}

Groundwater quality of Surjani Town was evaluated by using weighted arithmetic index method of WQI as proposed by Brown et al. (1970). Twelve physicochemical parameters (pH, TDS, EC, hardness, $\mathrm{Na}, \mathrm{K}, \mathrm{Ca}, \mathrm{Mg}$, $\mathrm{HCO}_{3}, \mathrm{Cl}, \mathrm{SO}_{4}$, and $\mathrm{NO}_{3}$ ) have been considered in WQI calculation.

\subsubsection{Calculation of Unit Weight}

First step in WQI calculation involves the estimation of unit weight (Wn) of all physicochemical parameters. The unit weight $(\mathrm{Wn})$ is inversely proportional to the recommended standards for the corresponding parameters.

$$
W n=k / S n
$$

Where,

$\mathrm{Wn}=$ unit weight for the $\mathrm{nth}$ parameter

$\mathrm{Sn}=$ Standards permissible value for $n$th parameter

$\mathrm{k}=$ proportionality constant which is calculated by following formula

$$
K=\frac{1}{\sum\left(\frac{1}{V S}\right)}
$$

\subsubsection{Calculation of Quality Rating}

Second step involves in the estimation of quality rating scale (Qn) for each parameter by using the following equation.

$$
Q n=[(V n-V i) /(V s-V i)] \mathrm{x} 100
$$

Where,

$\mathrm{Qn}=$ Quality rating of nth water quality parameters

$\mathrm{Vn}=$ Observed value of the water quality parameter obtained from laboratory analysis

$\mathrm{Vi}=$ Ideal value, in most cases $\mathrm{Vi}=0$ except in certain parameters like $\mathrm{pH}$ and dissolved oxygen which has $\mathrm{Vi}=7$ and $\mathrm{Vi}=14.6$ respectively

$\mathrm{Vs}=$ Recommended WHO standard of the water quality parameter 
Table 1. Analytical technique used for measuring physico-chemical parameters in collected samples

\begin{tabular}{cc}
\hline $\begin{array}{c}\text { Physicochemical } \\
\text { Parameters }\end{array}$ & Analytical Methods \\
\hline pH & pH meter (JENCO 6230N) \\
TDS and EC & EC meter (Eutech Cyber Scan CON 11) \\
Na and K & Flame photometer (Model No. Jenway PFP7) \\
Ca and Mg & EDTA titration \\
$\mathbf{S O}_{4}$ & Gravimetric method \\
$\mathrm{Cl}^{\mathrm{HCO}}$ & Standard titration method using silver nitrate \\
$\mathrm{NO}_{3}$ & Standard titration method \\
\end{tabular}

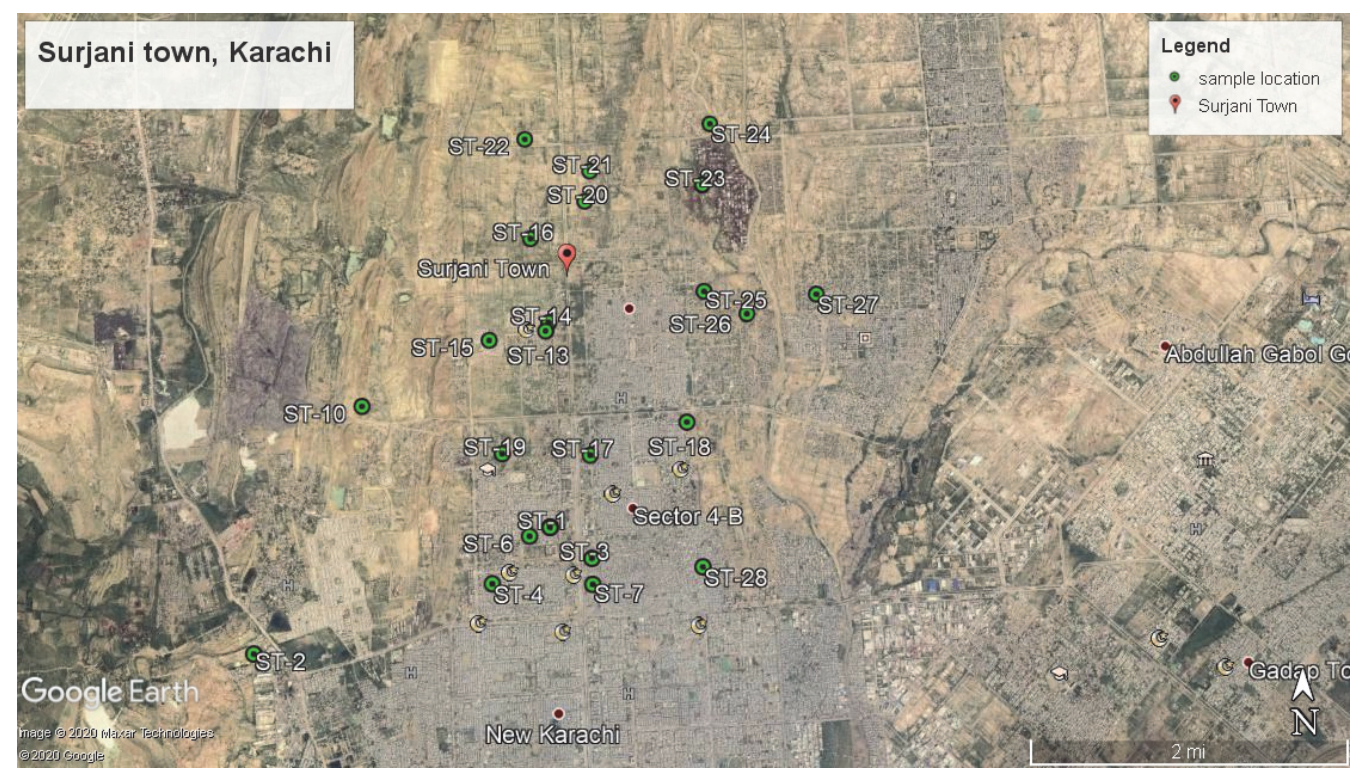

Figure 1. Map showing sample locations of Surjani Town, Karachi

\subsubsection{Calculation of WQI}

WQI is calculated by aggregating the quality rating with the unit weight linearly by using the following equation:

$$
W Q I=\Sigma Q n W n / \Sigma W n
$$

Where,

$Q_{n}$ is the quality rating of $n$th water quality parameter

$W_{n}$ is the unit weight of $n$th water quality parameter.

In last step, the calculated WQI value is classified into five categories in order to testify its suitability for human consumption. The maximum permissible WQI for drinking purpose was taken as 100 score.

\section{Results and Discussion}

\subsection{Physicochemical Characteristics}

Description of groundwater chemistry and its comparison with WHO standards have been summarized in Table 2 . Data reveal that groundwater $\mathrm{pH}$ is highly fluctuating and varies between acidic to alkaline (ranges $=6.5-7.6$; mean: 7.0) but within the permissible limit of WHO (6.5 - 8.5). Extremely wide range of total dissolved salts (TDS) 
and total hardness (TH) are observed (range: $609-28100 \mathrm{mg} / \mathrm{l}$ and $670-19750 \mathrm{mg} / \mathrm{l}$ ) in collected samples. Extremely violating TDS concentration is reported (Mean: $11946 \mathrm{mg} / \mathrm{l}$ ) which is twenty-three times higher than the permissible limit of WHO $(500 \mathrm{mg} / \mathrm{l})$. However, only three wells (ST-3, ST- 4 and ST- 14) have permissible TDS concentration (range $=609-847 \mathrm{mg} / \mathrm{l})$.

Table 2. Physicochemical and Statistical descriptive of groundwater chemistry and its comparison with WHO standards

\begin{tabular}{|c|c|c|c|c|c|c|c|c|c|c|c|c|}
\hline \multirow[b]{3}{*}{$\begin{array}{c}\text { Sample } \\
\text { Code }\end{array}$} & \multirow[b]{3}{*}{ pH } & \multirow{2}{*}{\multicolumn{3}{|c|}{ Physical parameter }} & \multicolumn{8}{|c|}{ Chemical parameter } \\
\hline & & & & & \multicolumn{4}{|c|}{ Major Cation } & \multicolumn{4}{|c|}{ Major Anion } \\
\hline & & $\begin{array}{l}\text { TDS } \\
\text { ppm }\end{array}$ & $\begin{array}{c}\mathbf{E C} \\
(\mathbf{m s} / \mathbf{c m})\end{array}$ & $\underset{(\mathrm{mg} / \mathrm{l})}{\text { Hardness }}$ & $\underset{(\mathrm{mg} / \mathrm{l})}{\mathrm{Na}}$ & $\begin{array}{c}\mathrm{K} \\
(\mathrm{mg} / \mathrm{l} \\
\text { ) }\end{array}$ & $\underset{(\mathrm{mg} / \mathrm{l})}{\mathrm{Ca}}$ & $\underset{(\mathbf{m g} / \mathrm{l})}{\mathbf{M g}}$ & $\begin{array}{c}\mathrm{HCO3} \\
(\mathrm{mg} / \mathrm{l})\end{array}$ & $\underset{(\mathrm{mg} / \mathrm{l})}{\mathrm{Cl}}$ & $\underset{(\mathrm{mg} / \mathrm{l})}{\mathrm{SO}_{4}}$ & $\begin{array}{c}\mathrm{NO}_{3} \\
(\mathrm{mg} / \mathrm{l})\end{array}$ \\
\hline ST-1 & 6.7 & 21800 & 43.7 & 6900 & 8500 & 49 & 1400 & 826.2 & 925 & 15035 & 2897.84 & 1.09 \\
\hline ST-2 & 6.5 & 16700 & 33.5 & 8500 & 7080 & 68 & 1740 & 1008.45 & 1050 & 9394 & 2653.64 & 0.16 \\
\hline ST-3 & 7.5 & 802 & 1600 & 760 & 240 & 28 & 68 & 143.37 & 1475 & 195 & 211.64 & 0.98 \\
\hline ST-4 & 7.14 & 609 & 1216 & 670 & 118 & 33 & 108 & 97.2 & 850 & 106 & 122.1 & 3.72 \\
\hline ST-5 & 7.49 & 6490 & 12.98 & 1220 & 4700 & 37 & 164 & 196.83 & 450 & 2399 & 18445.24 & 0.78 \\
\hline ST-6 & 7.41 & 1270 & 2.5 & 1180 & 420 & 27 & 112 & 218.7 & 1000 & 372 & 301.18 & 2.33 \\
\hline ST-7 & 6.9 & 24600 & 49.2 & 10000 & 9500 & 52 & 1400 & 1579.5 & 2725 & 7302 & 927.96 & 12.06 \\
\hline ST-8 & 7.18 & 7070 & 15.36 & 3500 & 5000 & 41 & 324 & 653.67 & 775 & 2630 & 3191 & 17.22 \\
\hline ST-9 & 7 & 20750 & 5.47 & 3000 & 3300 & 25 & 284 & 556.47 & 3050 & 744 & 830 & 27.66 \\
\hline ST-10 & 7.07 & 10800 & 21.5 & 6350 & 6000 & 61 & 792 & 1061.91 & 1025 & 3704 & 3053 & 28.89 \\
\hline ST-11 & 6.91 & 17500 & 35 & 8250 & 7800 & 53 & 1100 & 1336.5 & 625 & 4183 & 3077 & 46.75 \\
\hline ST-12 & 7.6 & 5100 & 10.2 & 3000 & 3500 & 46 & 276 & 561.33 & 1325 & 850 & 1498 & 6.65 \\
\hline ST-13 & 7.16 & 2640 & 5.28 & 4750 & 3300 & 50 & 494 & 854.145 & 925 & 762 & 521 & 55.93 \\
\hline ST-14 & 6.7 & 847 & 1697 & 2300 & 265 & 25 & 64 & 520.02 & 2125 & 159 & 8067 & 23.16 \\
\hline ST-15 & 6.84 & 1660 & 33.1 & 7500 & 12000 & 56 & 1200 & 1093.5 & 675 & 8543 & 2979 & 26.88 \\
\hline ST-16 & 7.34 & 25400 & 50.8 & 9500 & 11000 & 80 & 1100 & 1640.25 & 625 & 13577 & 2271 & 6.69 \\
\hline ST-17 & 7.07 & 22000 & 45.6 & 9450 & 9500 & 30 & 2000 & 1081.35 & 725 & 14304 & 4005 & 3.34 \\
\hline ST-18 & 7.04 & 1260 & 75 & 5350 & 8500 & 52 & 1080 & 643.95 & 875 & 4874 & 2922 & 44.4 \\
\hline ST-19 & 7.02 & 24500 & 80 & 10100 & 9300 & 49 & 2100 & 1178.55 & 275 & 13187 & 2824 & 26.22 \\
\hline ST-20 & 6.65 & 28100 & 118 & 12500 & 10000 & 56 & 2000 & 1822.5 & 1125 & 8330 & 3402 & 0.41 \\
\hline ST-21 & 6.87 & 3180 & 91 & 12500 & 14000 & 45 & 90 & 2982.825 & 1400 & 2658 & 3834 & 5.33 \\
\hline ST-22 & 6.51 & 3400 & 105 & 19750 & 22700 & 46 & 5600 & 1397.25 & 300 & 9926 & 2613 & 0.3 \\
\hline ST-23 & 6.8 & 6660 & 785 & 4900 & 4200 & 32 & 420 & 935.55 & 1875 & 2871 & 993 & 14.97 \\
\hline ST-24 & 7.09 & 6390 & 59 & 4400 & 5500 & 20 & 460 & 789.75 & 3375 & 1595 & 627 & 5.06 \\
\hline ST-25 & 6.9 & 19700 & 114 & 9500 & 8000 & 49 & 1760 & 1239.3 & 525 & 9571 & 1457 & 19.02 \\
\hline ST-26 & 7.3 & 8260 & 58 & 4700 & 6800 & 35 & 396 & 901.53 & 3450 & 921 & 1009 & 8.37 \\
\hline ST-27 & 6.7 & 26200 & 75 & 9500 & 13000 & 40 & 1400 & 1458 & 2900 & 10280 & 5275 & 23.04 \\
\hline ST-28 & 6.8 & 20800 & 95 & 8500 & 10000 & 47 & 1440 & 1190.7 & 3000 & 5884 & 2377 & 76.32 \\
\hline Max & 7.6 & 28100 & 1697 & 19750 & 22700 & 80 & 5600 & 2982.825 & 3450 & 15035 & 18445 & 76.3 \\
\hline Min & 6.5 & 609 & 2.5 & 670 & 118 & 20 & 64 & 97.2 & 275 & 106 & 122 & 0.16 \\
\hline Mean & 7.006 & 11946 & 233.292 & 6733.214 & 7293.678 & 44 & 1049 & 998.903 & 1409 & 5513 & 2942 & 17.4 \\
\hline S.D & 0.295 & 239.5 & 475.5 & 4337.8 & 4920.8 & 13.9 & 1119 & 601 & 988.8 & 4871 & 3491.8 & 19.2 \\
\hline $\begin{array}{l}\text { WHO } \\
\text { limit }\end{array}$ & $\begin{array}{l}6.5- \\
8.5\end{array}$ & $\begin{array}{c}\mathbf{5 0 0} \\
\text { ppm }\end{array}$ & & 500 & $\begin{array}{l}200 \\
\mathrm{mg} / \mathrm{l}\end{array}$ & $\begin{array}{c}12 \\
\mathrm{mg} / \mathrm{l}\end{array}$ & $\begin{array}{l}200 \\
\mathrm{mg} / \mathrm{l}\end{array}$ & $\begin{array}{l}150 \\
\mathrm{mg} / \mathrm{l}\end{array}$ & $\begin{array}{l}300 \\
\mathrm{mg} / \mathrm{l}\end{array}$ & $\begin{array}{l}250 \\
\mathrm{mg} / \mathrm{l}\end{array}$ & $\begin{array}{l}500 \\
\mathrm{mg} / \mathrm{l}\end{array}$ & $\begin{array}{c}10 \\
\mathrm{mg} / \mathrm{l}\end{array}$ \\
\hline
\end{tabular}

\subsection{Water Solute Chemistry}

Concentration of sodium and potassium ions is highly variable in the groundwater of study area (118-22700 $\mathrm{mg} / 1$ and $20-80 \mathrm{mg} / 1$ respectively) where the mean values of both cations (mean: $7293.678 \mathrm{mg} / \mathrm{l}$ and $44 \mathrm{mg} / \mathrm{l}$ ) showed the occurrence of very high concentration against corresponding WHO recommended limits. Only three wells have shown sodium concentration $<300 \mathrm{mg} / \mathrm{l}$ which are within the limit or marginally high values (Table 2 ). Likewise, distribution pattern of calcium and magnesium are also found to be very heterogeneous (range: $64-5600 \mathrm{mg} / \mathrm{l}$ and 
$97-2982 \mathrm{mg} / \mathrm{l})$. On the other hand, the mean concentration of $\mathrm{Ca}$ and $\mathrm{Mg}$ ions $( \pm 1000 \mathrm{mg} / \mathrm{l})$ are five and six times higher than the WHO admissible limit $(200 \mathrm{mg} / \mathrm{l})$ and $(150 \mathrm{mg} / \mathrm{l})$ respectively (Table 2).

Chloride $(\mathrm{Cl})$ and sulphate $\left(\mathrm{SO}_{4}\right)$ are the dominant anions followed by bicarbonate $\left(\mathrm{HCO}_{3}\right)$ and nitrate $\left(\mathrm{NO}_{3}\right)$. The mean concentration of chloride, sulfate and bicarbonate (Mean: $5513 \mathrm{mg} / 1,2942 \mathrm{mg} / \mathrm{l}$ and $1409 \mathrm{mg} / \mathrm{l}$ ) ions are extremely variable which are fluctuating between $106-15035,122-18445$ and 275-3450 mg/l respectively. Data revealed that about one third of total samples show remarkably high chloride content (range: 5885 - 15035 $\mathrm{mg} / \mathrm{l})$. Surprisingly high sulfate content $(18445 \mathrm{mg} / \mathrm{l})$ is reported in ST-5 well (Table 2). Similarly, high bicarbonate content (range: $1000-3450 \mathrm{mg} / \mathrm{l}$ ) is reported in $50 \%$ of the total samples which is seven times higher than the permissible limit of $300 \mathrm{mg} / \mathrm{l}$ for drinking water (WHO, 2004). Likewise, nitrate content varied between 0.16 $76.3 \mathrm{mg} / \mathrm{l}$ with a mean of $17.4 \mathrm{mg} / \mathrm{l}$, where about half of the collected samples $(\mathrm{n}=14)$ showed nitrate content $>10$ $\mathrm{mg} / \mathrm{l}$ which have objectionable concentration up to $76.3 \mathrm{mg} / \mathrm{l}$ (Table 2).

Table 3. WHO standard values (Vs) and unit weights (Wn) of their corresponding parameters

\begin{tabular}{|c|c|c|c|c|}
\hline Parameters & $\begin{array}{c}\text { WHO Standard } \\
\text { Vs }\end{array}$ & $1 / \mathrm{Vs}$ & $\begin{array}{c}K(\text { constant }) \\
K=\frac{1}{\sum\left(\frac{1}{V s}\right)}\end{array}$ & $\begin{array}{l}\text { Unit weight } \\
\mathbf{W n}=\mathrm{k} / \mathrm{Vs}\end{array}$ \\
\hline pH & 8.5 & 0.12 & 2.9 & 0.34 \\
\hline TDS (mg/L) & 500 & 0.002 & 2.9 & 0.006 \\
\hline Hardness (mg/L) & 500 & 0.002 & 2.9 & 0.006 \\
\hline $\mathrm{Na}(\mathrm{mg} / \mathrm{L})$ & 200 & 0.005 & 2.9 & 0.0145 \\
\hline K (mg/L) & 12 & 0.083 & 2.9 & 0.24 \\
\hline $\mathrm{Ca}(\mathrm{Mg} / \mathrm{L})$ & 75 & 0.013 & 2.9 & 0.04 \\
\hline $\operatorname{Mg}(\mathrm{mg} / \mathrm{L})$ & 150 & 0.007 & 2.9 & 0.02 \\
\hline $\mathrm{HCO3}(\mathrm{mg} / \mathrm{L})$ & 300 & 0.003 & 2.9 & 0.01 \\
\hline $\mathrm{Cl}(\mathrm{mg} / \mathrm{L})$ & 250 & 0.004 & 2.9 & 0.012 \\
\hline SO4 (mg/L) & 250 & 0.004 & 2.9 & 0.012 \\
\hline NO3 (mg/L) & 10 & 0.1 & 2.9 & 0.29 \\
\hline
\end{tabular}

\subsection{Water Quality Index (WQI)}

Groundwater chemistry was determined to evaluate the water quality index (WQI) of Surjani Town for drinking purpose as proposed by Brown et al (1970). Generally, water quality index is the reflection of composite influence of individual water quality parameter on the overall quality of water (Mitra and ASABE member, 1998). For computing WQI, the WHO standards for drinking water parameters have been taken into account. Twelve physicochemical parameters (pH, TDS, EC, Hardness, Na, K, Ca, Mg, HCO3, Cl, SO4 and NO3) have been selected which are mainly based on their direct influence for deteriorating groundwater quality for human consumption (Priya and Vidya, 2019). Further, the values of these parameters will proportionally increase WQI value (Priya and Vidya, 2019).

Table 4. Calculation of water quality index of Surjani Town

\begin{tabular}{|c|c|c|c|c|c|c|c|c|}
\hline Parameters & $\begin{array}{c}\text { Observed } \\
\text { Value } \\
(\text { Vn) }\end{array}$ & $\begin{array}{c}\text { WHO } \\
\text { standard } \\
(V s)\end{array}$ & $\begin{array}{c}\text { Ideal } \\
\text { Value } \\
\text { (Vi) }\end{array}$ & $V n-V i$ & $\begin{array}{l}\text { Vs- } \\
\text { Vi }\end{array}$ & & $\begin{array}{c}\text { Unit } \\
\text { weight } \\
\text { Wn=k/Vs }\end{array}$ & $Q n * W n$ \\
\hline pH & 7.006 & 8.5 & 7 & 0.006 & 1.5 & 0.04 & 0.34 & 0.0136 \\
\hline TDS (mg/L) & 11946 & 500 & 0 & 11946 & 500 & 2389.2 & 0.006 & 14.335 \\
\hline
\end{tabular}




\begin{tabular}{|c|c|c|c|c|c|c|c|c|}
\hline $\begin{array}{c}\text { Hardness } \\
(\mathrm{mg} / \mathrm{L})\end{array}$ & 6733.21 & 500 & 0 & 6733.214 & 500 & 1346.64 & 0.006 & 8.08 \\
\hline $\mathrm{Na}(\mathrm{mg} / \mathrm{L})$ & 7293.68 & 200 & 0 & 7293.678 & 200 & 3646.84 & 0.0145 & 52.88 \\
\hline K (mg/L) & 44 & 12 & 0 & 44 & 12 & 366.67 & 0.24 & 88 \\
\hline $\mathrm{Ca}(\mathrm{Mg} / \mathrm{L})$ & 1049 & 75 & 0 & 1049 & 75 & 1398.67 & 0.04 & 55.9 \\
\hline $\operatorname{Mg}(\mathrm{mg} / \mathrm{L})$ & 998.90 & 150 & 0 & 998.90 & 150 & 665.94 & 0.02 & 13.32 \\
\hline $\begin{array}{l}\text { HCO3 } \\
(\mathrm{mg} / \mathrm{L})\end{array}$ & 1408.93 & 300 & 0 & 1408.93 & 300 & 469.64 & 0.01 & 4.7 \\
\hline Cl (mg/L) & 5513.13 & 250 & 0 & 5513.13 & 250 & 2205.25 & 0.012 & 26.46 \\
\hline SO4 (mg/L) & 2942.32 & 250 & 0 & 2942.32 & 250 & 1176.93 & 0.012 & 14.123 \\
\hline NO3 (mg/L) & 17.418 & 10 & 0 & 17.42 & 10 & 174.18 & 0.29 & 50.5 \\
\hline & & & & & & & $\sum W n=0.99$ & $\sum Q n W n=328.3$ \\
\hline \multicolumn{9}{|c|}{ WQI $=331.62$} \\
\hline
\end{tabular}

First step in WQI calculation involves the estimation of unit weight (Wn) assigned to all selected physicochemical parameters. By assigning unit weights, all the concerned parameters of different units and dimensions are transformed into common scale (Priya and Vidya, 2019). The recommended standard values (Vs) and unit weights (Wn) of their corresponding parameters in WQI assessment are represented in Table 3. It is showing that the parameters such as $\mathrm{pH}, \mathrm{K}$ and $\mathrm{NO}_{3}$ which is usually required in least amount has more unit weight because the recommended water quality standard (Vs) is inversely proportional to unit weight Wn (Kumar and Dua, 2008).

Second step involves the determination of quality rating of all selected parameters by using the formula: $Q n=$ $100^{*}[(V n-V i) /(V s-V i)]$. If quality rating $Q n=0$ means complete absence of pollutants, while $0<Q n<100$ implies that the pollutants are within the prescribed standard and when $Q n>100$ indicates that the pollutants are above the standards (Gungoa, 2016). Except $\mathrm{pH}, Q n$ values of all physicochemical parameters are above 100 which suggest that the groundwater is highly polluted (Table 4). Likewise, the parameters such as $\mathrm{K}>\mathrm{Ca}>\mathrm{Na}>\mathrm{NO}_{3}$ is showing highest influencing values in WQI computation as shown in Table 4. These parameters are exhibiting maximum prominence in WQI calculation.

In last step, computed WQI values are classified into five categories to evaluate the corresponding water quality status, the best value of water quality was given a low range and the bad level is designated to higher values as shown in Table 5 (Yogendra and Puttaiah, 2008).

Table 5. WQI range and corresponding water quality status (after Brown et al., 1972).

\begin{tabular}{ccc}
\hline WQI & Status & Possible usages \\
\hline $\mathbf{0 - 2 5}$ & Excellent & Drinking, irrigation and industrial \\
$\mathbf{2 5 - 5 0}$ & Good & Domestic, irrigation and industrial \\
$\mathbf{5 1 - 7 5}$ & Fair & Irrigation and industrial \\
$\mathbf{7 6 - 1 0 0}$ & Poor & Unsuitable for drinking \\
$\mathbf{1 0 1 - 1 5 0}$ & Very poor & Restricted use of irrigation \\
$>\mathbf{1 5 0}$ & Unfit for drinking & Proper treatment required for use \\
\hline
\end{tabular}

The result of water quality index shows that the groundwater of Surjani town is inadmissible for drinking purpose in WQI rating scale $(\mathrm{WQI}=331.62)$ which is consistent with the extremely high concentration of measured physicochemical parameters (Table 2). The non-suitability of groundwater is mainly attributed to the anthropogenic activities such as waste disposal, agricultural activities and pollution from nearby open dumpsite (Ameen, 2019). Moreover, the computed results are comparable with the recent study carried out in Surjani Town (Khan, et al., 2020) which reveals that the groundwater is being contaminated by leachate migration from nearby Jam Chakro landfill site. 


\section{Conclusion}

Weighted arithmetic index method of WQI has been applied to evaluate the groundwater quality of Surjani Town for drinking purpose. The computed WQI results (331.62) clearly shows that the groundwater is highly deteriorated and unfit for drinking purpose in terms of WQI rating scale. The high WQI values are consistent with the extremely high concentration of measured physicochemical parameters in study area. It is concluded that the groundwater is mainly influenced by anthropogenic activities from adjacent landfill site which seems to be the main factor for groundwater contamination.

\section{Acknowledgement}

Authors are indebted to Department of Geology, University of Karachi for providing the analytical facilities.

\section{References}

Abbasi, S. A. (2002). Water quality indices. Elsevier. Amsterdam.

Abtahi, M., Mohebbi, M. R., Saeedi, R., Montazeri, A., Vaghefi, K. A., Labbafi, S., Oktaie, S., \& Mohagheghian, A. (2013). Assessment of water quality in groundwater resources of Iran using a modified drinking water quality index (DWQI). Ecological Indicators, 30, 28-34. http://dx.doi.org/10.1016/j.ecolind.2013.02.008

Ameen, A. H. (2019). Spring water quality assessment using water quality index in villages of Barwari Bala, Duhok, Kurdistan Region, Iraq. Applied Water Science, 9, 176. https://doi.org/10.1007/s13201-019-1080-z

Brown, R. M., McClelland, N. I., Deininger, R. A., Tozer, R. G. (1970). A water quality index: Do we dare? Water \& Sewage Works, 117, 339-343.

Brown, R. M., McClelland, N. I., Deininger, R. A., \& O’Connor, M. F. (1972). A water quality indexcrashing the physiological barrier. Indic. Environ. Qual, 1, 173-182.

Diersing, N. (2009). Water Quality: Frequently Asked Questions. Florida Keys National Marine Sanctuary, Key West, FL. Retrieved from http://floridakeys.noaa.gov/scisummaries/wqfaq.pdf.

Gungoa, V. (2016). Use of Water Quality Indices for Water Quality Assessment in Small Island State: A Case Study in the Northern Aquifer of Mauritius. International Journal of Sciences: Basic and Applied Research, 30, $142-150$.

Horton, R. K. (1965). An index number system for rating water quality. Journal-Water Pollution Control Federation, 37, 300-305. http://dx.doi.org/10.26479/2019.0502.08

Khan, A., Khan, S. A., Saeed, Z., \& Naz, B. (2020). Impact of Leachate Percolation on Groundwater Quality near the Municipal Open Dumpsite (Jam Chakro): A Case Study of Surjani Town, Karachi, Pakistan. International Journal of Ground Sediment \& Water, 10, 541-556.

Khan, F., Husain, T., \& Lumb, A. (2003). Water quality evaluation and trend analysis in selected watersheds of the Atlantic Region of Canada. Environmental Monitoring and Assessment, 88, 221-242. http://dx.doi.org/ 10.1023/a:1025573108513.

Khwakaram, A. I., Majid, S, N., \& Hama, N, Y. (2012). Determination of water quality index (WQI) for qalyasan stream in sulaimani city/ kurdistan region of iraq. Ijapes, 2(4), 148-157.

Kumar, A., \& Dua, A. (2008). Water quality index for assessment of water quality of river ravi at madhopur (india). Global journal of environmental sciences, 8(1), 49-57. http://dx.doi.org/ 10.4314/gjes. v8i1.50824

Lumb, A., Sharma, T., \& Bibeault, J. F. (2011). A review of genesis and evolution of waterquality index (WQI) and some future directions. Water Qual. Expo. Health, 3, 11-24.

Mitra, B. K., \& ASABE Member. (1998). Spatial and temporal variation of ground water quality in sand dune area of aomori prefecture in Japan.

Priya, T. D., \& Vidya, A. K. (2019). Evaluation of water quality index using physicochemical parameters of treated domestic sewage water. Life Science Informatics Publications, 5(2), 98.

Sargaonkar, A., \& Deshpande, V. (2003). Development of an overall index of pollution for surface water based on a general classification scheme in Indian context. Environmental Monitoring and Assessment, 89, 43-67. http://dx.doi.org/ 10.1023/A:1025886025137

Srebotnjak, T., Carr, G., Sherbinin, A., \& Rickwood, C. (2012). A global water qualityindex and hot-deck imputation of missing data. Ecol. Indic, 17, 108-119. http://dx.doi.org/10.1016/J.ECOLIND.2011.04.023

Yogendra, K., \& Puttaiah, E. (2008) Determination of water quality index and suitability of an urban waterbody 
in Shimoga Town, Karnataka. Paper presented at the Proceedings of Taal 2007: The 12th World Lake Conference.

\section{Copyrights}

Copyright for this article is retained by the author(s), with first publication rights granted to the journal.

This is an open-access article distributed under the terms and conditions of the Creative Commons Attribution license (http://creativecommons.org/licenses/by/4.0/). 